\title{
Perspective Study on Coastal Disaster Management at Andhra Pradesh
}

\author{
Smt. M.Suma ${ }^{1}$, Mr. P.S. Balaram ${ }^{2}$ \\ ${ }^{1}$ Faculty of Aditya Degree College,Kakinada, and Research scholar(P.T) Department of Commerce and \\ Management ,Andhra University, Vizag,(A.P), INDIA). \\ ${ }^{2}$ Associate Professor at Aditya PG. \& Degree College, Kakinada, E.G.Dt, (AP) and INDIA
}

\begin{abstract}
A large and growing part of the population now lives close to coasts. The threats posed to coastal populations and infrastructure by rising sea levels and extreme events such as storm surges. There is an urgent need for action now in order to limit the adverse effects of climate change upon ecosystems and human society. Andhra Pradesh has a coastline of $974 \mathrm{~km}$. Among which the Bay of Bengal Sea. Coast has frequently been affected by cyclones and inundated by storm surges. Erosion is noticed at Uppada, Visakhapatnam and Bhimunipatnam.in Andhra Pradesh coastal areas. Coastal zones are facing a lot of problems. They are landfill, dredging, and pollution caused by urban, industrial and agricultural development, coastal erosion, loss of coastal habitat, storm surge, tsunami and the global warming induced sea level rise etc. Coastal erosion is caused due to both natural processes and anthropogenic interventions. The unceasing act of winds, waves, tides and currents leads to shore movement or littoral drift along certain coastal stretches it increasingly clear that climate change will change and damage the coastal environment. in this paper my study analyze the coastal disaster management issues like effects and remedial techniques, it is useful to the disaster and risk management studies.
\end{abstract}

Key Words: Cyclone, Erosion, Tsunami, Risk management

\section{Introduction}

The frequency of Tropical Cyclones (TCs) in the NIO covering the Bay of Bengal and theArabian Sea is the least in the world (7\% of the global total), their impact on the east coast of India as well as the Bangladesh coast is relatively more devastating. This is evident from the fact that in the last 270 years, 21 of the 23 major cyclones (with a loss of about 10,000 lives or more) worldwide Occurred over the area surrounding the Indian subcontinent (India and Bangladesh). This is primarily due to the serious storm tide effect in the thirteen coastal states and Union Territories (UTs) in the country, encompassing 84 coastal districts, are affected by tropical cyclones. Four states (Tamil Nadu, Andhra Pradesh, Orissa and West Bengal) and one UT (Pondicherry) on the east coast and one state (Gujarat) on the west coast are more Vulnerable to hazards associated with cyclones.

\section{Objectives Of The Study}

1. Scenario of Disaster management.

2. Effects on living hoods.

3. Remedial Methods and Suggestions.

\section{Description Of The Study}

Andhra Pradesh coast are quite intensive and have been highly productive both from food production and economy points of view while on the other the coast has been subjected to a number of natural hazards which are quite frequent, sudden and unwarranted. The summer monsoon depressions and severe storms cause extensive loss of life, apart from severe damage to property and crops across the Andhra coast. In addition to these unwarranted events, a regular and cyclic phenomena like erosion and deposition is prevalent in many parts of the A.P. coast. One of the striking examples is severe erosion that has been significantly damaging the Kakinada-Uppada coast. Andhra Pradesh state has $900 \mathrm{~km}$ of coastline on the east coast of India and an estimated 870,000 fishers living mainly in fishing communities. Uppada is a sea fishing community of around 13,000 inhabitants. The community has changed considerably over time: technological advances have influenced the types of boats used and the variety of fishing gear and coastal erosion has seen the village move several times. The increasing globalization of the fishing industry - particularly the advent of shrimp fishing, has impacted upon Uppada (e.g. affecting catch prices). Alternative communal resources are limited in Uppada. 


\section{Methodology}

This paper examines how these policies are attempting to tackle and Take into consideration issues related to climate change adaptation. Priority will be given to extract out how ground level applications are incorporated or recommended into the policy Formulation process. Data will be collected through key person interviews and secondary Data sources.

\section{Reviews}

In addition to the mounting empirical data on direct implications of climate change for natural and human systems, evidence is increasing for indirect climate change phenomena such as sea-level rise. Rising sea levels and associated marine intrusion into terrestrial environments are predicted to be among the most serious eventual consequences of climate change. The many complex and interacting factors affecting sea levels create considerable uncertainty in sea-level rise projections: conservative estimates are on the order of $0.5-1.0 \mathrm{~m}$ globally, while other estimates are much higher, approaching $6 \mathrm{~m}$. Marine intrusion associated with 1-6 m sealevel rise will impact species and habitats in coastal ecosystems severely. Examining areas most vulnerable to such impacts may allow design of appropriate adaptation and mitigation strategies. We present an overview of potential effects of $1 \mathrm{~m}$ and $6 \mathrm{~m}$ sea level rise for coastal conservation areas in the Indian Subcontinent. In particular, we examine the projected magnitude of areal losses in relevant biogeographic zones, ecoregions, protected areas (PAs) and important bird areas (IBAs). In addition, we provide a more detailed and quantitative analysis of likely effects of marine intrusion on 22 coastal PAs and IBAs that provide critical habitat for birds in the form of breeding areas, migratory stopover sites and overwintering habitats. Several coastal PAs and IBAs are predicted to experience higher than 50\% areal losses to marine intrusion. We explore consequences of such inundation levels for species and habitats in these areas.

The coastal zones are highly resourceful and dynamic. The coastal zones are facing many natural hazards such as coastal erosion, Storm surge, Tsunami, coastal flooding and sea level rise. It is obvious that the future sea level rise due to human induced global warming is the main threat to the coastal zone. The global mean sea level is continuing to rise during the 21 st century. In this regards, coastal vulnerability assessment due to sea level rise is needed. Globally, there are many coastal vulnerability assessment tools and techniques such as CM (Common Methodology), SURVAS (Synthesis and Up scaling of Sea Level Rise Vulnerability Assessment Studies), DIVA (Dynamic Interactive Vulnerability Assessment) and CVI (Coastal Vulnerability Index). In the present paper discuss the various aspects of sea level rise and coastal vulnerability index assessment in details.

Many studies across the globe has predicted the rise in the Sea level as a result of theglobal warming caused by the rising concentration of the atmospheric carbon diooxide,methane, carbon mono oxide and chlorofluorocarbons. The paper aims at analyzing the sea level data from the nine-tide gauge monitoring stations across the country. The most significant and direct impact of the sea level rise may be the shoreline retreat and the loss of the coastal wetland as a result of the inundation of the low land. We attempt to find the time trend of the sea level rise and document the positive, significant and increasing trend for the majority of the monitoring stations in India. Total wetland loss along the nine coastal states under different possible scenario and the under projected and estimated trend scenario is evaluated.

Extreme sea levels generated by strong tangential wind stress and normal atmospheric pressure gradients at the sea surface due to tropical cyclones were studied for the western sector of the Bay of Bengal (the east coast of India). The maritime states along the coast, hit by different intensities of cyclones, are West Bengal, Orissa, Andhra Pradesh, and Tamil Nadu. Based on precise historical data for the period 1891-2007, statistical projections have been made on the probable intensities of tropical cyclones for various return periods. With the help of numerical models developed at Indian Institute of Technology Delhi, maximum probable surges along the coast were simulated. The local tide effect was considered in the computations as rise of sea level would be greater if the cyclone crosses the coast during high tide. The total water elevation is computed by linearly adding the local tide and wave setup to the surge simulated along the coast. In the present study, an assessment of cyclone risk and vulnerability was evolved, which is an important component of the information used to create sustainable local-level development action plans for preparedness and mitigation.

India has a long coastline of approximately $8,000 \mathrm{~km}$. There are two distinct cyclone seasons: premonsoon (May-June) and post-monsoon (October-November). The impact of these cyclones is confined to the coastal districts, the maximum destruction being within $100 \mathrm{~km}$ from the centre of the cyclones and on either side of the storm track. Most casualties are caused due to coastal inundation by tidal waves, storm surges and torrential rains. The occurrence of tropical cyclone is almost a common natural phenomenon.The Indian Ocean is one of the six major cyclones-prone regions of the world. In India, cyclones from Indian ocean usually occur between April and May, and also between October and December. The eastern coastline is more prone to cyclones than the western coast. About 80 percent of total cyclones generated in the region hit the eastern coast. Out of approximately six cyclones formed every year, two to three may be severe. 
Thelivelihood security of the coastal communities and ecological security of the coastal zones of India is already under stress due to high population density, rapid urbanization and industrial development, high rate of coastal environmental degradation and frequent occurrence of natural disasters such as cyclones and storms. This made more than 100 million people, who directly or indirectly depend on coastal natural resources for their livelihood, vulnerable. The problem is going to be further aggravated by increase in sea level rise due to climate change. It has been projected that along the Indian coast sea level would rise by 39 to $57 \mathrm{~cm}$ by 2050 and 78 to $114 \mathrm{~cm}$ by 2100 due to climate change (Unnikrishnan et al, 2006). The coastal zone in India, particularly the east coast is vulnerable to hydrometeorological hazards such as cyclones, floods and geophysical hazards like tsunami. Meteorological data show that more than 1000 cyclonic disturbances occurred in the Bay of Bengal during the last century; out of which over 500 were either depressions and over 400 were either cyclonic storms or severe cyclonic storms. Out of 205 severe cyclones for which records are well documented, 55 affected the coastal zone of Tamil Nadu, 59 crossed the coastal areas of Andhra Pradesh, 58 hit Orissa coast and 33 struck West Bengal. Depending on the location, the risk of hydrometeorological hazards ranges from moderate to high and that of geophysical hazards from low to moderate. A recent simulation study showed an increase in occurrence of cyclones in the Bay of Bengal in the increased Green House Gas scenario, particularly in the postmonsoon period. The same study also indicated that wind speeds associated with cyclones will also reach maximum increased due to climate change (Unnikrishnan et al, 2006)

India has been traditionally vulnerable to natural disasters on account of its unique geo-climatic conditions. Floods, droughts, cyclones, earthquakes and landslides have been a recurrent phenomena. About $60 \%$ of the landmass is prone to earthquakes of various intensities; over 40 million hectares is prone to floods; about $8 \%$ of the total area is prone to cyclones and $68 \%$ of the area is susceptible

to drought. In the decade 1990-2000, an average of about 4344 people lost their lives and about 30 million people were affected by disasters every year. The loss in terms of private, community and public assets has been astronomical.

\section{Coastal Zone Management Issues Challenges Facing At Kakinada Port Area}

A combined approach to coastal protection and resource conservation simplifies the process of management and leads to more balanced decisions on what constitutes acceptable development. The setback requirement that protects beachfront structures from erosion and storm waves can also preserve turtle-nesting sites on the back beach. Similarly, restriction on clearing of mangrove swamps will not only conserve an economically valuable resource, but also maintain a physical defense against storm tides. Severe beach erosion is a problem of all coastal nations. A long coastline of about $7,516 \mathrm{~km}$ of flat coastal terrain, shallow continental shelf, high population density, geographical location and physiological features of its coastal areas makes India, in the North Indian Ocean (NIO) Basin, extremely vulnerable to cyclones and its associated hazards like storm tide (the combined effects of storm surge and astronomical tide), high velocity wind and heavy rains.

\subsection{Population pressure}

Fishing in East Godavari District is shaped largely by its physical geography which sub-divides the district into two ecological zones. This is evident from the development of different modes of fishing and the distribution of castes specializing in these different modes. South of Kakinada is the Godavari River Delta. The northern part of the delta is mangroves which drain into Kakinada Bay, enclosed by the sand spit of Hope Island. This ecological zone is dominated by the Agnikula Kshatriya caste who is traditionally river fishers. Increasingly, members of the Agnikula Kshatriya use small wooden crafts and rafts to fish in Kakinada Bay. All the mechanized boats using trawling gear owned by fisher castes are Agnikula Kshatriya who have migrated predominately to Yetimoga on the outskirts of Kakinada. A major factor underpinning the tragedy of the commons, as well as several other manifestations of stress on the livelihoods of the communities, has been the enormous growth in population size in the coastal districts over the last three decades. Most communities have doubled their populations over this period, which resulted in further demands on the natural resources as well as more pressure on the living conditions.

\subsection{Wave/tidal actions}

Changes in tidal and wave actions have been mostly reported by the people involved in fishing and related activities, although their deeper effects - increased Stalinization of ground water, erosion and reduced living space - are felt more widely. As a result of increased intensity of wave actions, the shoreline does not slope gently into the sea allowing the tides and waves to play out their energies before reaching the beach; it drops abruptly into the sea, causing the waves to be more intense and damaging when they hit the shoreline. 


\subsection{Natural disasters}

Although an increase in natural disasters like cyclones is considered to be a strong indicator of Climate change, there is less evidence that this is happening in the coastal districts of Andhra Pradesh. The incidence of cyclones may have remained largely the same as ever, what may have increased is their intensity and their area of distribution. The last two cyclones to have hit the Andhra Pradesh coast - Cyclone Laila and Cyclone Nilam in 2013 November philin and Hellene cyclones have left significant damages in their wake, affecting agriculture and fisheries very badly. Another critical change with respect to the cyclones has been that they too have ceased to be seasonal: specific months - May \& November - were considered as the 'cyclone months' and the administration could be prepared to deal with them in those months. Unlike in the Again, as with everything that we have discussed so far (reduced freshwater downstream vs reduced seawater upstream; increased erosion in one place vs increased siltation at another), there is also a flipside to the incidence of floods. According to the coastal fishers, annual monsoonal floods, which allowed a good mix of fresh and saline waters, reduced seawater temperatures and brought nutrients into the sea, were a necessary requisite for the wellbeing of their fisheries. However, with the loss of regularity of the floods, this is not happening and that - according to the fishers - is one reason for the poor fish catches in their areas. A few trends relating to climate change, e.g., change in wind patterns and rainfall, seasonal fluctuations and natural disasters, are attributed to the natural factors. For the respondents, the global phenomena such as sea-level rise, global warming and El Nino Effect, are totally new ideas and their ability to relate a change in their local environment actions.

\subsection{Damage Overview}

Data for this damage assessment has been collected through field visits to each of the main Affected stretches of coastline; review of state government damage assessment reports and technical reports; and consultation with relevant divisions in each district. Although the overall impact of the tsunami on the east coast was severe, damage to coastal protection structures was limited. Most are designed to cope with high wind waves, and survived the tsunami with only minor damage. The Rubble Mound Seawalls (RMSs) survived and were reported to have saved many lives and properties. However, most of the small coastal embankments to protect roads and other infrastructure did not have sufficient depth to cope, and suffered severe damage.

\subsection{Beach Erosion}

Annual cyclones contribute to beach erosion. The Forest Department has planted casuarinas trees near the shore of many villages, especially those beyond Konapapapeta, to reduce the impact of cyclones. According to the fishers living along the coast north of Kakinada, the beach has been reduced by several hundred meters 58 over the last twenty-five years. It is claimed by some that the Godavari spit, Hope Island, has created currents which have sped up the process, especially at Uppada. In villages like Uppada and Konapapapeta, where the village was originally near the shore, this erosion is most obvious. The beaches there are narrow and the majority of housing has been moved farther inland. In Mulapeta, the village begins beyond a flood plain. From maps of 1903, substantial land has been washed away in Mulapeta during the past 100 years. Furthermore, changing contours of the rivers and sea shore have been observed.

\section{Coastal Management And Protection Schemes}

7.1 Disasters and food insecurity are directly interconnected. Floods, hurricanes, tsunamis and other hazards destroy agricultural, livestock and fishing infrastructure, assets, inputs and production capacity. They interrupt market access, trade and food supply, reduce income, deplete savings and erode livelihoods. Drought, plant pests and diseases such as locusts and armyworms, and animal diseases like African swine fever have a direct economic impact by reducing or eliminating farm production, by adversely affecting prices and trade, and by decreasing farm income. Economic crises such as soaring food prices reduce real income, force the poor to sell their assets, decrease food consumption and reduce their dietary diversity. Disasters create poverty traps that increase the prevalence of food insecurity and malnutrition.

7.2 Floods, hurricanes, tsunamis and other hazards destroy agricultural infrastructure andassets, crops, inputs and production capacity. Drought alone has caused more deaths during the last century than any other physical hazard. Asia and Africa rank first among continents in the number of people directly affected, while Africa has a high concentration of deaths associated with drought 4 . These natural hazards have a direct impact on agriculture and food security. They interrupt market access, trade and food supply to the cities. They reduce income, deplete savings, and erode livelihoods. They also have a negative consequence for animal production by reducing range productivity and rangeland yields, leading to food insecurity, overgrazing and degradation of ecosystems. Livestock is central to the livelihoods of the poor. It forms an integral part of mixed farming systems. It is an important source of employment, Income, quality food, fuel, draught power and fertilizer. Fisheries and aquaculture, a sector that is a critical contributor to food supply, income generation and food security, also 
suffers tangible losses as a result of natural disasters, including damage to fishing infrastructure and productive assets such as docks, landing and processing facilities, boats and fishing gear. In addition, diseases threaten fish and contribute to food and nutrition insecurity among rural populations dependent on fish farming. Over 500 million people depend, directly or indirectly, on fisheries and aquaculture for their livelihoods. Fish also provides essential nutrition to three billion people, including at least 50 percent of the animal protein and essential mineral intake of 400 million people in the poorest countries. New transboundary aquatic animal diseases continue to appear, causing losses in aquaculture and capture fisheries and adversely affecting local economies.

\section{Suggestions}

8.1 The government built a $3 \mathrm{~km}$ seawall to check the erosion but it offered temporary relief," The government then tried to correct the situation by building a series of groynes, or small breakwaters. This aggravated the problem and erosion spread to neighboring "The structural interventions were done without much thought. It caused saline ingress into groundwater and deprived many of livelihoods in this area.

8.2 India already has one of the biggest such initiatives, called Integrated Coastal Zone Management Project (ICZMP) financed by the World Bank since 2010. With an estimated cost of US \$286 million, four ICZMP pilot projects have been undertaken in the country - a national coastal management programme and one pilot project each in West Bengal, Odisha and Gujarat. In West Bengal, two areas in the Sundarbans have been identified for ICZMP implementation. Main objectives of the project are conservation of the mangroves, introduction of coastal protection measures, economic development and setting up cyclone shelters. These types of initiative are allocating other coastal sensitive areas in Tamil Nadu and Andhra Pradesh to protect and conservation.

8.3 In India, coast has been defined in the Coastal Regulation Zone (CRZ) notification of 2011. It says coast is the stretch lying along the seafront up to $500 \mathrm{~m}$ from the high tide line. HTL is the line on the land up to which the highest water line reaches during springtide. Some activists call it a "narrow understanding of coast". But the government perspective differs. Shailesh Nayak, secretary of Ministry of Earth Sciences, says, "Coastal zone is a complex system. It is not an easy task to define it." Development along the coast should happen in a systematic way with minimal impact to the coastal ecosystem, he suggests.

8.4 Deforestation is a problem for several reasons. Reduced forest cover will provide reduced Water retention services in the more variable climate of the future. This will contribute to Increased runoff, flooding and soil erosion during rains as well as greater scarcity of water During dry seasons. The scarcity of water will be an impediment for rainfall and irrigated Cultivation, livestock rearing and public water supply. Deforestation will also constrain the Future use of forests as safety nets for supplementing subsistence and earning cash income. In essence, deforestation will limit livelihood strategies based on both farm and nonfarming Activities.

\section{Conclusions}

9.1 The environments are often subjected to degradation at an alarming rate leaving a very gloomy future. Due to increasing coastal population and growth in mechanized boat operations all along the coastline, the socioeconomic status of the fishermen community is now in a fragile state. It is time that a thorough understanding of the socio-economic status of the coastal population, their limitations to compete with affluent.

9.2 Fish population is reduced to one fourth due to environmental degradation caused by municipal waste disposal and industrial pollution.

9.3 The concentration industries and the direct or indirect disposal of industrial disposal of industrial effluents and municipal drains to estuaries, rivers or near shore waters cause water pollution.

9.4 In India, a project coming up along the coast needs environmental clearance from the Union Ministry of Environment and Forests (MoEF) if mentioned under the permissible activities in the Coastal Regulation Zone (CRZ) notification of 2011. The project proponent applies to the state coastal zone management authority with an environmental impact assessment (EIA) and a marine impact assessment.

9.5 Industrial activity is not the only problem ailing the Indian coast. Environmental degradation (urban/industrial waste dumping in sensitive ecosystems, deforestation offshore oil exploration; practices affecting wetlands, mangroves, and marshy lands) 
9.6 Case of cyclones, there is no advance warning systems to warn people of the imminent flooding of their areas, which contribute to further increasing the extent of damages.

9.7 Uppadas coastal environment is under increasing development pressure, despite the island's exposure to significant shoreline erosion during storm conditions. Buildings need to be designed and constructed to protect human life and assets giving due respect the prevailing forces of nature. With appropriate planning regulations and building practices, Uppadas coastline properties can be protected from damage and a natural or semi-natural appearance preserved. Development policies in uppada.

9.8 Death and injury are the direct health impacts most commonly associated with extreme weather events. However, the environmental hazards left behind by natural disasters such as floods and hurricanes can also have a number of serious secondary health economic Conditions.

9.9 No finances to promote ground level adaptation. And Need to balance growth/development.

\section{References}

[1]. M. Zafar-ul Islam, Shaily Menon, Xingong Li \& A. Townsend Peterson, (2013). Forecasting ecological impacts of sea-level rise on coastal conservation areas in India, Journal of Threatened Taxa, 5(9), P- 4349-4358,

[2]. Manik Mahapatra, Ratheesh R. and Rajawat, (2013). sea level rise and coastal vulnerability assessment: a review, International Journal of Geology, Earth \& Environmental Sciences, 2013 Vol.3 (3, P- .67-80).

[3]. Dwijendra Nath dwivedi, Dr. Vinod Kumar Sharma (2005),.analysis of sea level rise and its impact on coastal wetlands of india, Proceedings of the 14th Biennial Coastal Zone Conference New Orleans.

[4]. Indu Jain, A.D. Rao, V. Jitendra, and S.K. Dube, (2010). Computation of Expected Total Water Levels along the East Coast of India, Journal of Coastal Research,26 (4), P- 681-687,

[5]. Vinod K Sharma, D Kaushik Ashutosh,(2012), Natural Disaster Management in India, YOJANA March 2012.

[6]. V Selvam, (2012), Climate change and Disaster Management in Coastal Areas, YOJANA March 2012,P- 51-55.

[7]. REPORT Government of India Ministry of Home Affairs National Disaster Management Division.PP2 Disaster Management in India - A Status Report, (2004).

\section{Bibliography}

[8]. National disaster management guidelines,management of cycolenes,national disaster management authority,government of india(2008)

[9]. Venkatesh salagrama, report rapid assessment on impact of climate change and community resilience to disasters in 9 coastal districts of Andhra Pradesh, analysis of district study data and preparation . (2013) 